\title{
基于生态系统服务价值的京津冀城市群 湿地主导服务功能研究
}

\author{
荔 㻟 $^{1,2}$, 蒋卫国 ${ }^{1,2}$, 王文杰 ${ }^{3}$, 吕金霞 ${ }^{1,2}$, 邓 越 ${ }^{1,2}$ \\ (1. 北京师范大学地理科学学部, 环境遥感与数字城市北京市重点实验室, 北京 $100875 ; 2$. 北京师范大学地 \\ 理科学学部,遥感科学国家重点实验室,北京 100875;3. 中国环境科学研究院,北京 100012)
}

\begin{abstract}
摘要: 湿地是地球三大生态系统之一, 在气候调节、水资源供给、净化环境等方面具有重要的 价值和作用。基于 1990-2015 年 6期土地生态遥感解译数据和社会经济数据, 通过修正生态系 统服务价值当量因子和计算湿地价值的内外部贡献率, 利用 GIS 定量研究了京津冀城市群及各个 城市 25 年间不同湿地类型、不同功能生态系统服务价值的变化, 并基于此进行功能定位。结果 表明: (1) 京津冀城市群湿地的生态系统服务价值呈现先上升后波动下降的趋势, 2015 年湿地 价值较 1990 年上升了 29.3 亿元, 主要是由于河渠、水库坑塘价值的增加, 以及水文调节、水资源 供给价值的增加; (2) 京津冀城市群的 13 个城市中, 天津市生态系统服务价值最高, 且东部沿海 区域湿地价值有增加趋势, 南部内陆城市不仅湿地面积少且价值逐年下降; (3)水文调节、水资 源供给和净化环境是京津冀城市群大部分城市湿地的主导功能, 而河渠、水库坑塘、滩地则是 提供服务功能的主要湿地类型。生态系统服务价值的减少与增加都与人类活动密切相关, 因 此了解湿地价值的变化趋势及变化原因, 明确湿地的功能定位, 不仅可以增强人们对湿地生态 的保护意识, 同时也为未来京津冀地区湿地的修复、恢复及可持续利用提供科学依据。
\end{abstract}

关键词: 京津冀城市群;湿地; 生态系统服务价值;功能定位

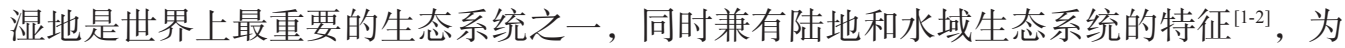
自然和人类提供了大量的资源 ${ }^{[3-4]}$ ，具有巨大的生态、经济和社会价值。但是随着气候变 化及城市化进程的加快, 湿地不断被侵占和破坏, 并引发了生物多样性降低、水污染等 一系列问题 ${ }^{[5]}$ 。近几十年来, 越来越多的研究人员对湿地展开了研究, 包括湿地的退化现

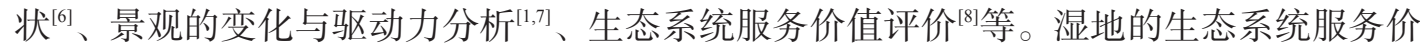
值评价作为湿地研究的重要分支，其目的在于从经济角度量化人类直接或间接从生态系 统中获得的利益 ${ }^{[9-10]}$ 。湿地的价值评价不仅对湿地的恢复和管理具有重要意义, 还有助于 提高人们对湿地的关注度。

生态系统服务概念的提出最早出现在 20 世纪 80 年代 ${ }^{[1]}$, 而后千年生态系统评估的研究 发表后，使得生态系统服务价值评价进入了新的发展阶段。目前，生态系统服务价值评价 的方法大体可以分为能值分析法、物质量评价法、价值量评价法 ${ }^{[12]}$ 。有研究人员分别利 用能值分析方法、InVEST 等模型核算了珠江三角洲、黑河流域和长江经济带的生态系统 服务功能及其价值 ${ }^{[13-15]}$, 利用市场价格法、影子价格法等对武汉市和四川南河国家湿地公

收稿日期：2019-03-27; 修订日期：2019-05-31

基金项目：国家重点研发计划项目（2016YFC0503002); 国家自然科学基金项目（41571077）

作者简介: 荔琢 (1996- ), 女, 内蒙古呼伦贝尔人, 博士研究生, 主要从事城市湿地与生态研究。

E-mail: lizhuo@mail.bnu.edu.cn

通讯作者: 蒋卫国 (1976- ), 男, 湖南衡阳人, 教授, 博士生导师, 主要从事水文遥感大数据分析、洪水灾害监测 评价及湿地生态空间模拟研究。E-mail: jiangweiguo@bnu.edu.cn 
园的生态系统服务价值进行计算 ${ }^{[16-17]}$ 。1997 年, Costanza 等 ${ }^{[18]}$ 对生态系统服务进行了划 分。而后，谢高地等人通过不断的修正，将生态系统服务功能分成了供给服务、调节服 务、支持服务和文化服务 4 个一级类别和 11 个二级类别, 并建立了中国陆地生态系统单 位面积服务价值表 ${ }^{[19-20]}$ 。目前, 有关湿地生态系统服务价值的研究很多, 但大部分研究仅 停留在价值本身，而没有进一步通过价值的结果对功能进行评估。湿地功能的价值有高 低之分, 即湿地的功能有主导和辅助之分, 因此, 依据价值评价的结果来进行功能定位 是十分必要的, 这将有助于更加精准与合理的制定湿地保护、恢复的政策和方案 ${ }^{[12]}$ 。

京津冀城市群是中国区域经济和社会发展最快的增长极之一㕵]。目前, 城市群的协 调发展面临着诸多问题，比如污染问题、生态问题等，而湿地作为生态系统中不可或缺 的一部分，在净化环境、气候调节等功能中发挥着重要的作用。因此，本文基于土地利 用数据和社会经济数据, 通过修正单位面积的生态系统服务功能当量因子，对 1990-2015 年京津冀城市群及各个城市不同湿地类型、不同服务功能的生态系统服务价值进行评 价，并依据结果进行功能定位。

\section{1 研究方法与数据来源}

\section{1 研究区概况}

京津冀城市群包括北京市、天津市，以及河北省境内的石家庄市、保定市、唐山 市、廊坊市、秦皇岛市、张家口市、承德市、沧州市、邯郸市、邢台市和衡水市，地处 $36^{\circ} 03^{\prime} \sim 42^{\circ} 40^{\prime} \mathrm{N} 、 113^{\circ} 27^{\prime} \sim 119^{\circ} 50^{\prime} \mathrm{E}$ ，是中国的政治、文化中心，也是中国北方经济的重 要核心区（图 1)。区域内湿地类型丰富，分布广泛。然而随着城市化进程和社会经济发 展的不断加快，京津冀城市群的生境质量下降 ${ }^{[22]}$, 湿地遭到较为严重的破坏，近 30 年间 其面积呈现出略微增长到快速减少的趋势，且破碎度增加，分布离散 ${ }^{[1]}$ ，使得整个湿地的 生态系统及其可持续发展面临较大的威胁。

\section{2 数据来源}

本文数据包括 1990-2015 年 6 期土地利用数据和社会经济数据。土地利用数据为中国 科学院地理科学与资源研究所刘纪远团队生产，该数据基于 Landsat 8 OLI、GF 2 号遥感 卫星数据进行解译，并利用无人机影像和野外考察对分类结果进行核查，二级类型分类 精度达 $90 \%$ 以上 ${ }^{[23]}$, 在本文中将其重采样至 $100 \mathrm{~m} \times 100 \mathrm{~m}$ 的分辨率。另外依据湿地公约 与陆健健划分的中国湿地类型, 选择水田、河渠、湖泊、水库坑塘、滩涂、滩地、沼泽 地 7 种土地利用类型作为本文研究的湿地 ${ }^{[1]}$ 。

社会经济数据主要来源于 1990-2015 年京津冀地区 13 个城市的统计年鉴以及中国农 业统计年鉴, 收集了包括粮食价格、粮食作物单产、粮食作物面积等数据。另外，还用 到了基于 SPOT、RapidEye 拼接的 $2.5 \mathrm{~m}$ 高分辨率遥感影像。

\section{3 研究方法}

\subsection{1 京津冀城市群湿地生态系统服务价值计算}

基于生态系统服务价值当量因子可以得到不同土地利用类型的不同生态系统服务功 能的价值 ${ }^{[0]}$ 。1 个标准的当量因子是指 $1 \mathrm{hm}^{2}$ 全国平均产量的农田每年自然粮食产量的经 济价值 ${ }^{[19]}$ 。因此，本文以谢高地等 ${ }^{[20]}$ 提出的价值当量为基础，依据京津冀地区的实际情 况，利用各城市各粮食作物产量、播种面积、全国平均价格，对生态系统服务价值当量 

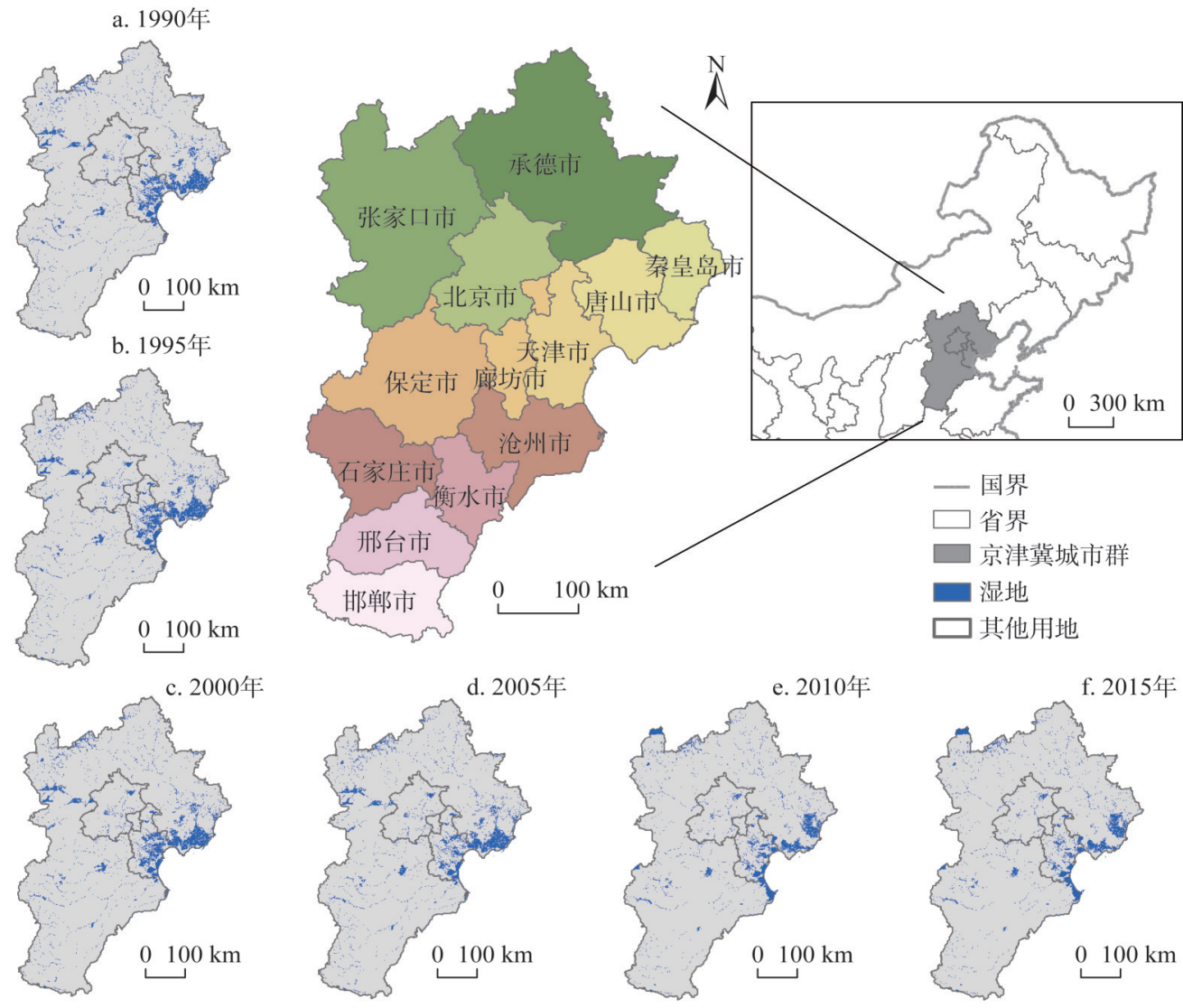

图 1 研究区地理位置及1990-2015 年湿地分布

Fig. 1 Geographical location of the study area and distribution of wetlands from 1990 to 2015

因子进行修正，计算粮食作物的经济价值：

$$
V C=\frac{1}{7} \sum_{i=1}^{n} \frac{m_{i} p_{i} q_{i}}{M}(i=1, \cdots, n)
$$

式中: $V C$ 为京津冀城市群各城市单位面积农田粮食作物的经济价值 $\left(\right.$ 元 $\left./ \mathrm{hm}^{2}\right) ; i$ 为作物 种类, $i=4$, 包括水稻、小麦、玉米和大豆; $p_{i}$ 为 $i$ 种粮食作物的全国平均市场价格 (元/t); $q_{i}$ 为 $i$ 种粮食作物单产 $\left(\mathrm{t} / \mathrm{hm}^{2}\right) ; m_{i}$ 为 $i$ 种粮食作物面积 $\left(\mathrm{hm}^{2}\right) ; M$ 为 $n$ 种粮食作物总面积 $\left(\mathrm{hm}^{2}\right) ； 1 / 7$ 是指 1 个当量因子的生态服务价值为研究区当年单位面积粮食价值的 $1 / 7^{[24]}$ 。

由于本文与谢高地等 ${ }^{[20]}$ 研究中的土地利用分类不一致，因此将水域的生态系统服务 当量赋给河渠、湖泊和水库坑塘, 湿地的服务当量赋给滩涂、滩地和沼泽。通过统计 1990-2015年京津冀地区水稻、小麦、玉米和大豆的价格、单产、播种面积等数据，得到 京津冀地区各市 1 个当量因子的生态系统服务价值（表 1)。而后根据不同湿地类型、不 同服务功能的当量因子 ${ }^{[20]}$, 得到各个市单位面积的湿地生态系统服务价值。

京津冀地区生态系统服务价值计算公式为:

$$
\begin{aligned}
& E S V_{i}=\sum_{j=1}^{m} A_{i} \times V C_{i} \\
& E S V_{j}=\sum_{i=1}^{n} A_{j} \times V C_{j}
\end{aligned}
$$

式中: $E S V_{i}$ 为湿地类型 $i$ 的生态系统服务价值, $m=11 ; E S V_{j}$ 为生态系统服务功能 $j$ 的价 
表 1 1990-2015 年各市 1 个当量因子的生态系统服务价值

Table 1 Ecosystem service value of one equivalent value in each city from 1990 to 2015

\begin{tabular}{lcccccc}
\hline & 1990 年 & 1995 年 & 2000年 & 2005年 & 2010 年 & 2015 年 \\
\hline 保定市 & 288.06 & 1067.98 & 778.36 & 1010.03 & 1775.48 & 1884.27 \\
沧州市 & 210.85 & 766.12 & 487.40 & 807.29 & 1500.01 & 1493.33 \\
承德市 & 338.99 & 1113.47 & 190.09 & 1031.35 & 1476.59 & 1332.67 \\
邯単市 & 294.65 & 950.69 & 732.73 & 1020.53 & 1737.03 & 2180.67 \\
衡水市 & 280.58 & 1054.64 & 747.21 & 1038.99 & 1697.16 & 1855.49 \\
廊坊市 & 267.60 & 1022.88 & 577.70 & 948.67 & 1690.31 & 1524.27 \\
秦皇岛市 & 388.59 & 1183.86 & 560.51 & 1031.18 & 1746.86 & 1688.08 \\
石家庄市 & 406.26 & 1318.60 & 953.17 & 1228.90 & 1847.11 & 2072.37 \\
唐山市 & 364.78 & 1206.93 & 676.38 & 1042.13 & 1857.03 & 1924.24 \\
邢台市 & 281.59 & 952.31 & 687.63 & 985.01 & 1664.82 & 1908.61 \\
张家口市 & 315.52 & 731.54 & 355.39 & 674.86 & 1199.31 & 1245.51 \\
天津市 & 182.05 & 1042.63 & 592.65 & 1036.90 & 1823.83 & 1560.08 \\
北京市 & 421.22 & 1256.92 & 682.85 & 873.54 & 1431.00 & 1731.06 \\
\hline
\end{tabular}

值, $n=7 ; A_{i} 、 A_{j}$ 分别为某一湿地类型 $i$ 的面积 $\left(\mathrm{hm}^{-2}\right)$ 和提供某生态系统服务 $j$ 的湿地面 积总和 $\left(\mathrm{hm}^{-2}\right) ; V C_{i} 、 V C_{j}$ 分别为类型 $i$ 和生态系统服务功能 $j$ 的单位面积生态系统服务价 值 $\left(\right.$ 元 $\left.\mathrm{hm}^{-2} \cdot \mathrm{a}^{-1}\right){ }^{[11]}$ 。

\subsection{2 京津冀城市群湿地功能定位}

湿地的功能众多，一般有主导功能和辅助功能之分，而主导功能则是指该区域内湿 地应该担负的主要职能和所要发挥的功用 ${ }^{[12]}$, 因此不同类型的湿地往往具有不同的主导 功能。本文在研究湿地生态系统服务价值的同时，根据结果对各个城市及城市群湿地的 功能进行定位。

主导功能是通过计算各功能的贡献率得到的，而贡献率又分为湿地内部贡献率和湿 地外部贡献率。湿地内部贡献率是指某区域内湿地的某单项功能价值在该区域内综合功 能价值中的贡献率大小, 湿地外部贡献率是指某区域内湿地的某单项功能价值在总研究 区内该功能价值总和中的贡献率大小 ${ }^{[12]}$ 。

湿地内部贡献率 $=$ 单项功能价值 $\div$ 综合功能价值

湿地外部贡献率 $=$ 单项功能价值 $\div$ 京津冀城市群该功能价值总和

\section{2 结果分析}

\section{1 京津冀城市群湿地生态系统服务价值的变化分析}

1990-2015 年京津冀城市群湿地的生态系统服务价值整体呈现先上升而后波动下降的 趋势（图 2)。1990年湿地价值为 663.31 亿元，是整个研究时段内的最低值。而后，1995 年湿地的价值达到最高值，为 710.81 亿元，较 1990 年上升了 $7.16 \%$ 。而后的十年间，建设 用地及农田的不断扩张和侵占，加之气候变暖、环境污染等一系列因素的影响，湿地面积 减少，进而使得湿地的生态系统服务价值分别下降了 $0.77 \%$ 和 $2.57 \%$ 。2 005 年后，京津冀 城市群湿地的生态系统服务价值变化幅度减小，呈现先增加后减少的趋势，2010年和 2015 年的湿地价值分别为 697.04 亿元和 692.59 亿元，变化率分别为 $1.41 \%$ 和 $-0.63 \%$ 。 
2.1.1 不同服务功能的生态系统服务价值变化 表 2统计了 1990-2015 年不同生态系统服 务功能的价值变化。整体来看, 生态系统服 务价值增长的功能包括水资源供给和水文调 节, 净化环境的价值是先升高后下降，其余 功能的价值均减少。水文调节价值最高, 其 次是净化环境。价值较少的功能为原料生产 和维持养分循环。结合价值总体的变化可以 发现，1990-1995 年价值的上升主要体现在 食物生产、水资源供给、净化环境和水文调 节四种价值的增加, 尤其是水文调节功能, 其价值增加了 46.3 亿元。而生态系统服务价

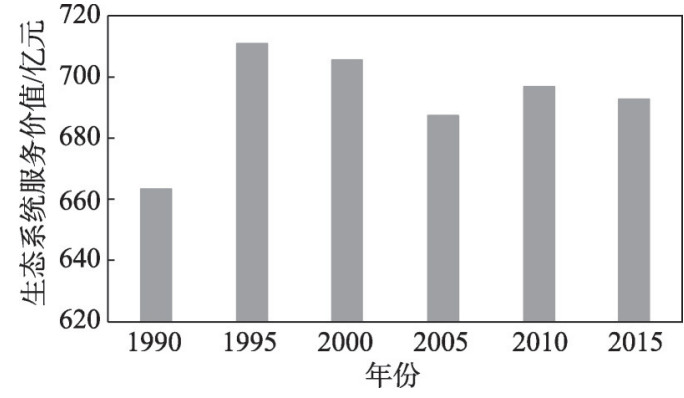

图 2 1990-2015 年京津冀城市群湿地 生态系统服务价值的变化

Fig. 2 Changes of wetland ecosystem service value in Jing-Jin-Ji Urban Agglomeration from 1990 to 2015

值变化最显著的五年是 2005-2010年，水资源供给、水文调节、生物多样性和美学景观功 能都出现了较大程度的增加或减少。由于水文调节功能的价值当量较高, 且变化幅度很 大, 大多数时间段里其他功能的减少不及水文调节功能的增加, 因此其增长可能导致整 个生态系统服务价值的增长。

表 2 不同服务功能的生态系统服务价值变化

Table 2 Changes of ecosystem service value of different service functions

(亿元)

\begin{tabular}{|c|c|c|c|c|c|c|c|c|c|c|c|}
\hline 年份 & $\begin{array}{l}\text { 食物 } \\
\text { 生产 }\end{array}$ & $\begin{array}{l}\text { 原料 } \\
\text { 生产 }\end{array}$ & $\begin{array}{c}\text { 水资源 } \\
\text { 供给 }\end{array}$ & $\begin{array}{l}\text { 气体 } \\
\text { 调节 }\end{array}$ & $\begin{array}{l}\text { 气候 } \\
\text { 调节 }\end{array}$ & $\begin{array}{l}\text { 净化 } \\
\text { 环境 }\end{array}$ & $\begin{array}{l}\text { 水文 } \\
\text { 调节 }\end{array}$ & $\begin{array}{l}\text { 土壤 } \\
\text { 保持 }\end{array}$ & $\begin{array}{c}\text { 维持养分 } \\
\text { 循环 }\end{array}$ & $\begin{array}{l}\text { 生物 } \\
\text { 多样性 }\end{array}$ & $\begin{array}{l}\text { 美学 } \\
\text { 景观 }\end{array}$ \\
\hline 1990 & 13.47 & 3.28 & 22.06 & 17.04 & 25.36 & 34.24 & 468.26 & 12.10 & 2.15 & 40.18 & 25.17 \\
\hline 1995 & 13.60 & 3.19 & 25.76 & 16.58 & 25.07 & 35.79 & 514.62 & 11.64 & 2.10 & 38.25 & 24.21 \\
\hline 2000 & 13.63 & 3.21 & 25.23 & 16.69 & 25.16 & 35.63 & 509.07 & 11.72 & 2.11 & 38.58 & 24.38 \\
\hline 2005 & 12.50 & 3.08 & 26.27 & 15.61 & 24.18 & 34.70 & 496.56 & 11.40 & 1.95 & 37.41 & 23.68 \\
\hline 2010 & 10.84 & 2.43 & 31.28 & 12.24 & 20.08 & 33.30 & 530.47 & 8.78 & 1.53 & 27.86 & 18.23 \\
\hline 2015 & 10.43 & 2.39 & 31.82 & 11.88 & 19.81 & 33.08 & 527.29 & 8.72 & 1.47 & 27.61 & 18.08 \\
\hline
\end{tabular}

2.1.2 不同湿地类型的生态系统服务 价值变化

图 3 为 1990-2015 年不同湿地类 型价值的变化。整体来看, 价值较 高的湿地类型为水库坑塘、河渠、 滩地和沼泽地，湖泊和水田的价值 接近, 滩涂在京津冀城市群内的面 积较小, 因此其价值最小。水田、 滩涂、滩地和沼泽地的价值一直呈 现下降趋势, 湖泊的价值是先上升 后下降, 河渠和水库坑塘的价值则 一直是上升的。尤其在 2005-2010年 间, 湿地各个类型的价值都发生了

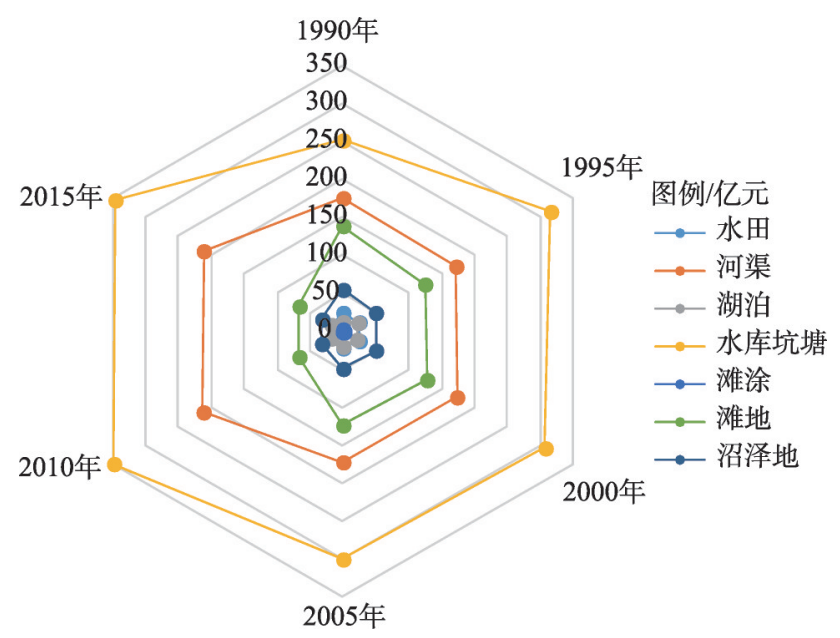

图 3 不同湿地类型的生态系统服务价值变化

Fig. 3 Changes of ecosystem service value of different wetland types 
较大的变化, 滩地和沼泽地快速下降, 河渠和水库坑塘快速上升。这十年里, 除了人们 开始保护和恢复湿地之外, 很大原因是由于沿海区域发展了大量的养殖业、盐场等，而 这些在土地利用数据中被分类为水库坑塘，水库坑塘的价值当量高于其他湿地类型，因 此水库坑塘价值的上升引起了整个城市群湿地生态系统服务价值的增加。

\section{2 各个市湿地生态系统服务价值的变化分析}

图 4 显示了 1990-2015 年间各个城市生态系统服务价值的变化。天津市的湿地面积 大，因此价值是最高的， 2000 年其生态系统服务价值为 230.29 亿元，接近当年城市群湿 地价值的三分之一。其次价值比较高的城市包括张家口市、唐山市、保定市和承德市, 北京市、秦皇岛市、石家庄市和沧州市湿地的生态系统服务价值处于中等，而廊坊市、 衡水市、邢台市和邯郸市的湿地价值比较低。整体来看, 大部分城市的湿地生态系统服 务价值呈现下降的趋势，但近几年承德市、秦皇岛市和沧州市的湿地价值升高。

1990-1995年间, 各个市湿地生态系统服务价值变化幅度非常小。其中发生较大变化的 城市为北京市，1995 年的价值较 1990 年增加了 $42.97 \%$, 其原因是水库坑塘的增加, 致使 水文调节、净化环境等功能价值的上升。而后的 5 年间, 13 个城市的湿地价值都呈现出

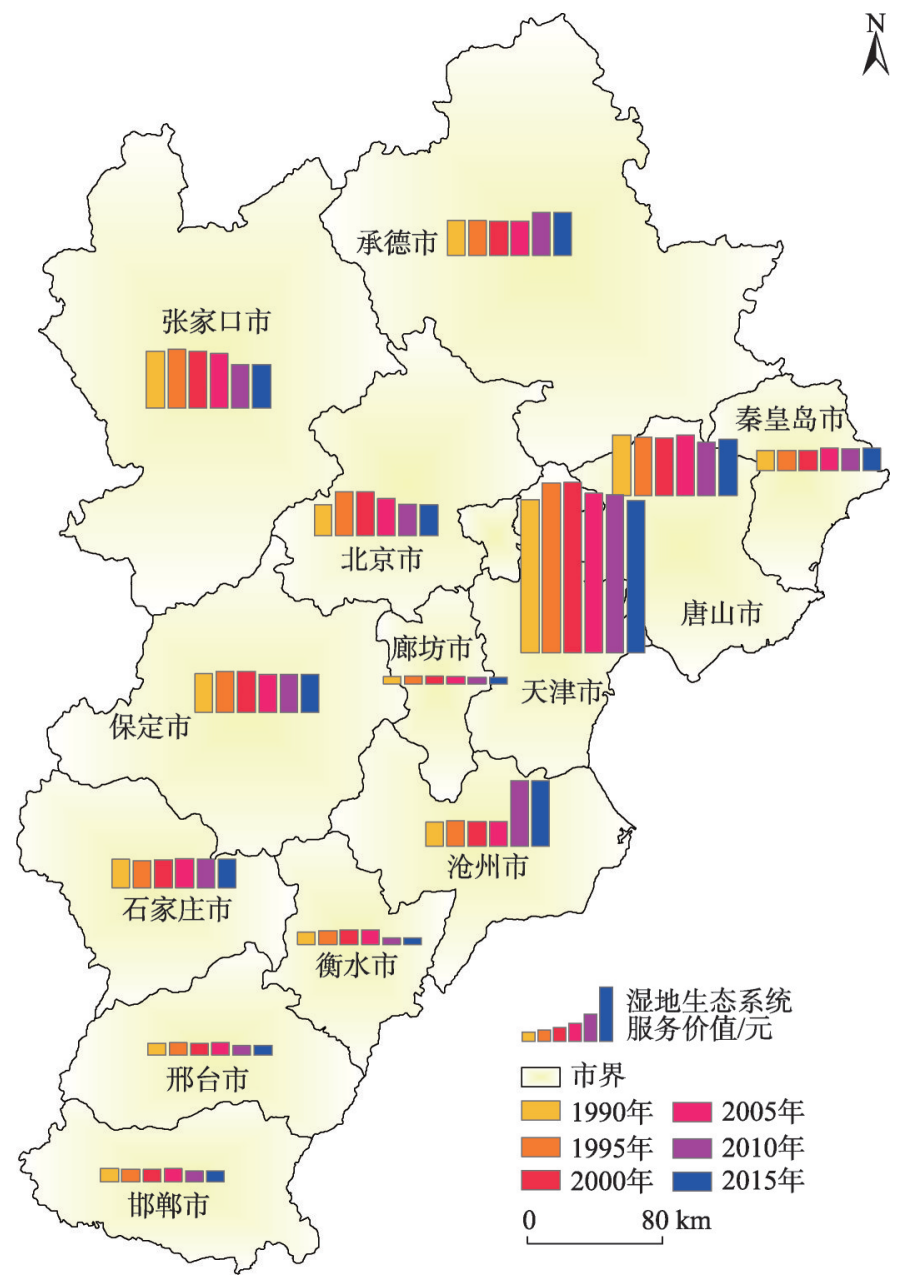

图 4 不同时段内各个市生态系统服务价值的变化

Fig. 4 Changes of ecosystem service value in different cities in different periods 
微小的波动, 除了保定市、衡水市、石家庄市和天津市有小幅度增加, 其他城市的价值 均略微下降。2000-2005 年间, 保定市和北京市的下降比较显著, 主要归结于滩地和水库 坑塘的减少，对整个城市的湿地价值造成了影响，同时邯䣋市和秦皇岛市的湿地价值有 比较明显的上升。2005-2010年是各个城市湿地生态系统服务价值变化最为显著的五年， 尤其是沧州市和承德市湿地价值的增长, 以及衡水市、邢台市、张家口市等市湿地价值 的下降。而后的五年里，各个城市变化幅度非常小，湿地的生态系统服务价值基本与 2010 年持平。

\section{3 京津冀城市群湿地功能定位}

\subsection{1 各市湿地功能定位分析}

京津冀城市群内各个城市湿地的功能定位依据 2015 年湿地生态系统服务价值的结果 以及内外部的贡献率进行排序（表 3)。水文调节是所有城市湿地的主导功能之一，其贡 献率均大于 $60 \%$ ，主要由河渠和水库坑塘提供，而其他的主导功能略有不同。

衡水市、廊坊市、天津市和北京市的主导功能都是水文调节、水资源供给和净化环 境, 而衡水市、廊坊市和北京市功能的外部贡献率较低, 所以未在表格中体现。天津市 湿地资源丰富，湿地生态系统服务价值非常高，使得天津市的 11 项功能的外部贡献率均 排在城市群前两位, 因此选择了内部贡献率更高的 3 项功能。除此之外未给出外部贡献 率的城市还有承德市、邯䣋市、石家庄市和邢台市, 这四个城市湿地功能的外部贡献率 则均属于较低的水平, 所以选择了内部贡献率更高的湿地功能作为主导功能。

其余的 5 个城市的湿地主导功能则各有不同。保定市除了水文调节和净化环境功能 较为重要外, 生物多样性在本市及城市群都占据比较重要的位置。沧州市的主导功能还 是以河渠、水库坑塘提供的水资源供给、水文调节和净化环境功能为主，同时该 3 项功 能在整个京津冀的贡献率也非常高。秦皇岛市和唐山市的情况较为类似, 都有较多的水 田和滩地，因此在食物生产、维持养分循环等功能上提供了更多的贡献率。张家口市有 较多的湿地公园, 沼泽地、河渠等湿地类型占比较大, 使得其生物多样性、美学景观等 功能的贡献率也更大。

\subsection{2 京津冀城市群不同湿地类型贡献率分析}

由于整个京津冀城市群无法计算其湿地的外部贡献率，因此依据内部贡献率确定了 对不同服务功能起主要作用的湿地类型（表 4)。水库坑塘和河渠依旧是占比比较大的两 种类型，尤其对水资源供给、净化环境和水文调节 3 种功能，其贡献率分别为 $85.76 \%$ 、 $74.66 \%$ 、 $86.27 \%$ 。另外，在食物和原料生产、维持养分循环方面，水田和滩地起到了更 多的作用。生物多样性和美学景观功能更多的出现在湿地公园、湿地保护区等地, 因此 滩地和水库坑塘的贡献率更大，其次沼泽地和河渠的贡献率也比较大。

\section{3 结论与讨论}

\section{1 结论}

本文对京津冀城市群不同湿地类型、不同生态系统服务功能的生态系统服务价值进 行评价, 并根据结果对城市群及各个城市的湿地进行功能定位。结果表明：（1）19902015 年京津冀城市群湿地生态系统服务价值呈现先增长后波动下降的趋势, 主要是由于 发展水产养殖业、种植业等人类活动导致了水库坑塘、水田等湿地类型面积的增加, 进 


\section{表 3 不同城市湿地功能的内外部贡献率}

Table 3 Internal and external contribution rates of wetland functions in different cities

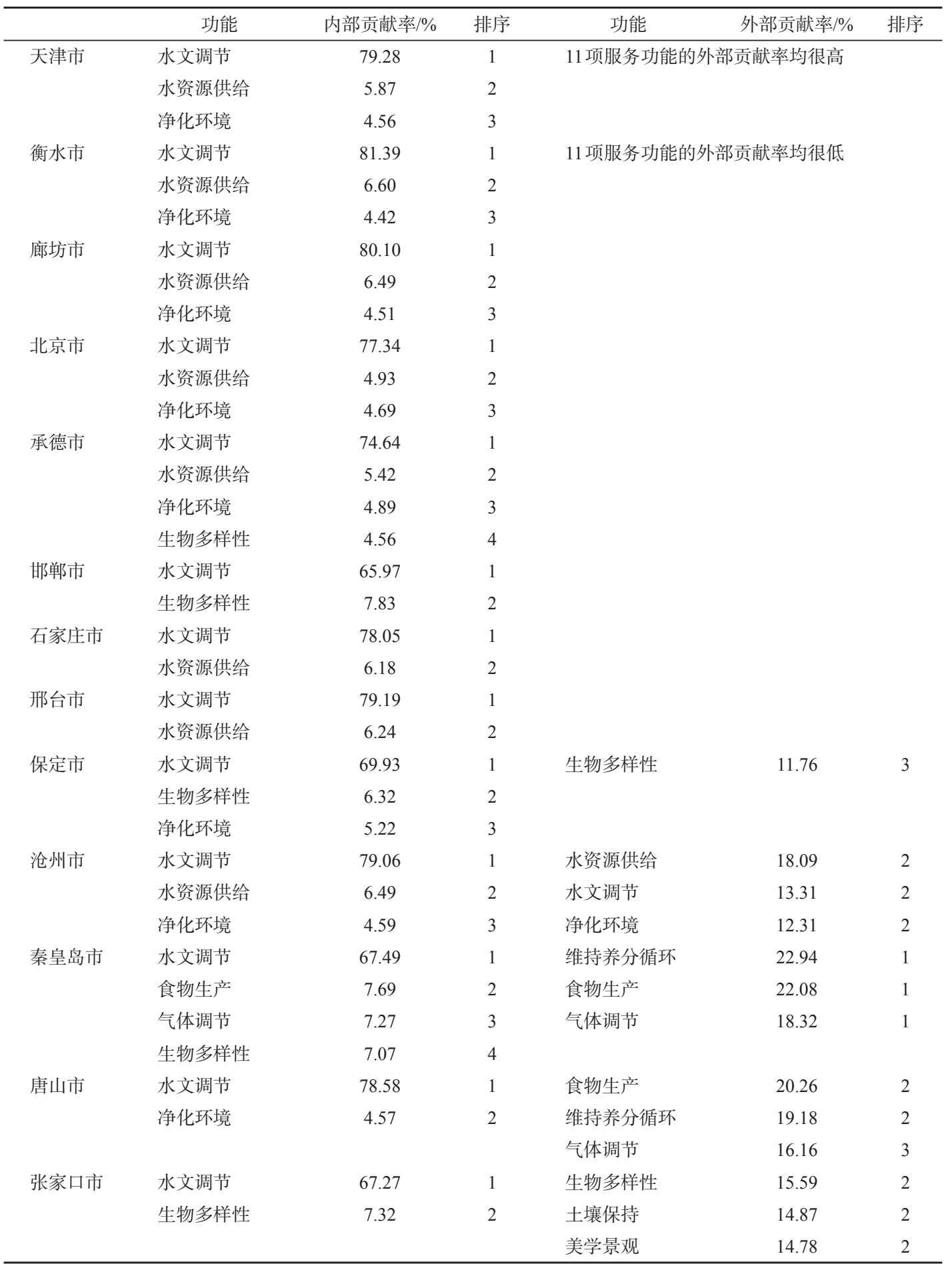

而影响到水文调节、水资源供给等生态系统服务功能价值的提高；（2）沧州市、秦皇岛 市和承德市近几年的湿地价值有明显增加，其余城市的湿地生态系统服务价值均有下降 趋势; (3) 水文调节、水资源供给和净化环境是京津冀城市群大部分城市的主导功能, 
表 4 对不同服务功能起主要作用的湿地类型

Table 4 Wetland types that play a major role in different service functions

\begin{tabular}{llc}
\hline 起主要作用的湿地类型 & 功能 & 内部贡献率 $/ \%$ \\
\hline 水田、水库坑塘 & 食物生产 & 76.62 \\
滩地、水库坑塘 & 原料生产 & 53.25 \\
水库坑塘、河渠 & 水资源供给 & 85.76 \\
水田、滩地、水库坑塘 & 气体调节 & 78.07 \\
水库坑塘、滩地、河渠 & 气候调节 & 88.58 \\
水库坑塘、河渠 & 净化环境 & 74.66 \\
水库坑塘、河渠 & 水文调节 & 86.27 \\
滩地、水库坑塘、河渠、沼泽地 & 土壤保持 \\
水田 & 维持养分循环 & 97.68 \\
滩地、水库坑塘 & 生物多样性 & 54.87 \\
滩地、水库坑塘 & 美学景观 & 61.93 \\
\hline
\end{tabular}

而城市群内起主要服务功能的湿地类型包括水库坑塘、河渠和滩地。人类活动对湿地价 值产生了巨大的影响，开发和利用湿地虽然会带来湿地价值的增加，但同时更要关注湿 地的保护与恢复，有针对性地制定湿地管护政策与措施，并予以及时跟进，助力京津冀 地区可持续发展和生态文明建设。

\section{2 讨论}

本文主要对京津冀城市群及各个城市 25 年间湿地生态系统服务价值的变化予以分析研 究, 并据此进行湿地的功能定位。结果表明, 湿地价值的变化主要由于水库坑塘、河渠等 湿地类型的水文调节、水资源供给等功能价值的变化所引起。而后通过进一步的探究发 现，这些变化与人类活动息息相关，这里利用高分辨率影像分析了几个典型区域（图 5)。
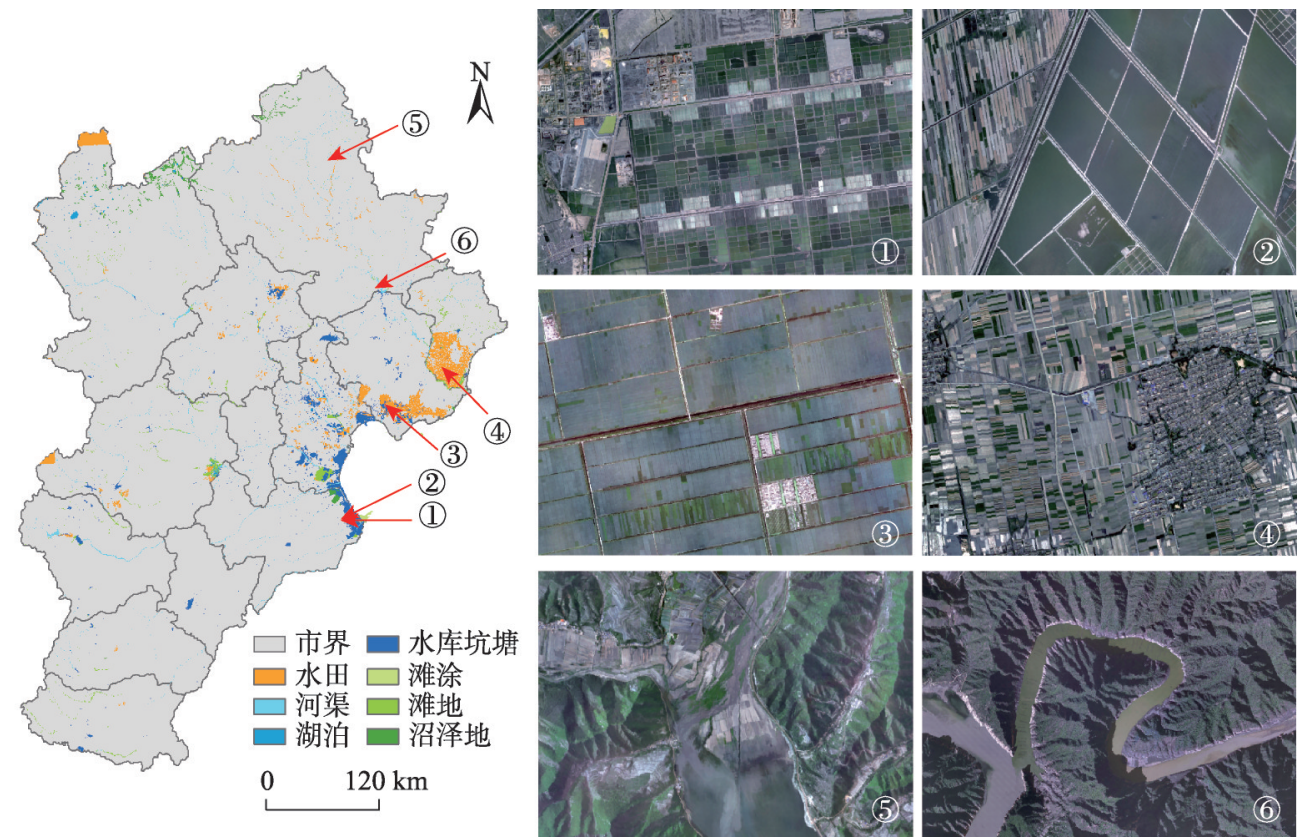

图 5 人类活动对湿地价值影响的几个典型区域

Fig. 5 Several typical regions of human activities affecting wetlands value 
1990-1995 年是价值增长最为迅速的五年，并在 1995 年湿地价值达到了整个研究时 段的最大值。这段时间降雨量的增加，人为的侵占和破坏较少，因此湿地的面积有所增 加 ${ }^{[1]}$ 。然而从 1995 年开始, 社会经济的迅速发展, 利益驱动, 人们忽略了对生态的保 护，尤其是 2000 年以后，随着京津冀一体化的提出，整个城市群的发展进人了新的阶 段。通过计算这二十几年间土地利用的转移和面积变化发现，大约有 $13.06 \%$ 和 $11.13 \%$ 的 湿地转变为农田和建设用地，导致湿地的价值随着面积的减少、人为的破坏以及自然因 素的影响而减少。而后，随着河北省沿海经济带等政策的实施，在沧州、秦皇岛、唐山 等地开始建造鱼塘、盐场，大力发展养殖业以及以水田为主导的种植业。图 5 中的区域 1 区域 4 分别为盐场、鱼塘及两处水田。除此之外, 京津冀城市群处于华北平原, 水资 源非常短缺，随着南水北调等补水工程的实施，湿地的水量也有所增多。而且近几年政 府开始重视生态的恢复和保护，建设京津冀生态协同圈，其中重点提到要全面恢复湿地 资源以及加强生态的治理，因此自然湿地受到了更多的保护，湿地价值随之增加。

本文的基础数据为土地利用分类数据，人工解译往往会出现偏差，图 5 中的区域 5 和区 域 6 均为河渠，然而在 2010 年和 2015 年的分类中，分别被归类为滩地和河渠，因此对价 值计算会有所影响。其次，利用粮食的产量、价格、面积修正生态系统服务价值当量因 子也会产生一些误差，尤其是粮食价格，很容易受到当年供求关系、成本等因素的影 响, 因此在今后的研究中应调整或替换更为合理的修正方法, 以得出更加准确的价值结果。

\section{参考文献(References):}

[1] 吕金霞, 蒋卫国, 王文杰, 等. 近 30 年来京津冀地区湿地景观变化及其驱动因素. 生态学报, 2018, 38(12): 44924503. [LYU J X, JIANG W G, WANG W J, et al. Wetland landscape pattern change and its driving forces in BeijingTianjin-Hebei region in recent 30 years. Acta Ecologica Sinica, 2018, 38(12): 4492-4503.]

[2] HU S J, NIU Z G, CHEN Y F, et al. Global wetlands: Potential distribution, wetland loss, and status. Science of the Total Environment, 2017, 586: 319-327.

[3] 张桃, 周立志, 陆胤吴, 等. 升金湖国家级自然保护区湿地生态系统服务价值的动态变化. 安徽农业大学学报, 2018, 45(5): 909-915. [ZHANG T, ZHOU L Z, LU Y H, et al. Dynamic ecosystem service value in the wetland of Shengjin Lake National Nature Reserve. Journal of Anhui Agricultural University, 2018, 45(5): 909-915.]

[4] 全世文, 秦光远, 王昌海. 北京市城市湿地价值评估. 中国人口·资源与环境, 2018, 28(7): 54-64. [QUAN S W, QIN G Y, WANG C H. Valuation of urban wetlands in Beijing. China Population, Resources and Environment, 2018, 28(7): 54-64.]

[5] MAO D H, LUO L, WANG Z M, et al. Conversions between natural wetlands and farmland in China: A multiscale geospatial analysis. Science of the Total Environment, 2018, 634: 550-660.

[6] DAVIDSON N C. How much wetland has the world lost? Long-term and recent trends in global wetland area. Marine and Freshwater Research, 2014, 65(10): 936-941.

[7] 徐晓龙, 王新军, 朱新萍, 等. 1996-2015 年巴音布鲁克天鹅湖高寒湿地景观格局演变分析. 自然资源学报, 2018, 33 (11): 1897-1911. [XU X L, WANG X J, ZHU X P, et al. Landscape pattern changes in alpine wetland of Bayanbulak Swan Lake during 1996-2015. Journal of Natural Resources, 2018, 33(11): 1897-1911.]

[8] 戴文远, 江方奇, 黄万里, 等. 基于 “三生空间” 的土地利用功能转型及生态服务价值研究: 以福州新区为例. 自然资 源学报, 2018, 33(12): 2098-2109. [DAI W Y, JIANG F Q, HUANG W L, et al. Study on transition of land use function and ecosystem service value based on the conception of production, living and ecological space: A case study of the Fuzhou New Area. Journal of Natural Resources, 2018, 33(12): 2098-2109.]

[9] QIAN D W, YAN C Z, XIU L N, et al. The impact of mining changes on surrounding lands and ecosystem service value in the Southern Slope of Qilian Mountains. Ecological Complexity, 2018, 36: 138-148.

[10] 商慧敏, 郗敏, 李悦, 等. 胶州湾滨海湿地生态系统服务价值变化. 生态学报, 2018, 38(2): 421-431. [SHANG H M, XI M, LI Y, et al. Evaluation of changes in the ecosystem services of Jiaozhou Bay coastal wetland. Acta Ecologica Sini- 
ca, 2018, 38(2): 421-431.]

[11] LIU W, ZHAN J Y, ZHAO F, et al. Impacts of urbanization-induced land-use changes on ecosystem services: A case study of the Pearl River Delta Metropolitan region, China. Ecological Indicators, 2019, 98: 228-238.

[12] 陈云浩, 蒋卫国, 赵文吉, 等. 基于多源信息的北京城市湿地价值评价与功能分区. 北京: 科学出版社, 2012: 167169. [CHEN Y H, JIANG W G, ZHAO W J, et al. Beijing Urban Wetland Value Assessment and Functional Partition Based on Multi-source Information. Beijing: Science Press, 2012: 167-169.]

[13] 杨青, 刘耕源. 湿地生态系统服务价值能值评估: 以珠江三角洲城市群为例. 环境科学学报, 2018, 38(11): 45274538. [YANG Q, LIU G Y. Wetland ecosystem services assessment based on emergy: A case of Pearl River Delta Urban Agglomeration. Acta Scientiae Circumstantiae, 2018, 38(11): 4527-4538.]

[14] 王蓓, 赵军, 胡秀芳. 基于 InVEST 模型的黑河流域生态系统服务空间格局分析. 生态学杂志, 2016, 35(10): 27832792. [WANG B, ZHAO J, HU X F. Spatial pattern analysis of ecosystem services based on InVEST in Heihe River Basin. Chinese Journal of Ecology, 2016, 35(10): 2783-2792.]

[15] XU X B, YANG G S, TAN Y, et al. Ecosystem services trade-offs and determinants in China's Yangtze River Economic Belt from 2000 to 2015. Science of the Total Environment, 2018, 634: 1601-1614.

[16] WANG Y, LI X M, ZHANG Q, et al. Projections of future land use changes: Multiple scenarios-based impacts analysis on ecosystem services for Wuhan city, China. Ecological Indicators, 2018, 94: 430-445.

[17] 陈翠, 刘贤安, 间丽丽, 等. 四川南河国家湿地公园生态系统服务价值评估. 湿地科学, 2018, 16(2): 238-244. [CHEN C, LIU X A, YAN L L, et al. Evaluation on ecosystem service values of Sichuan Nanhe National Wetland Park. Wetland Science, 2018, 16(2): 238-244.]

[18] COSTANZA R, ARGE R D, GROOT R D, et al. The value of the world's ecosystem services and natural capital. Nature, 1997, 387: 253-260.

[19] 谢高地, 鲁春霞, 冷允法, 等. 青藏高原生态资产的价值评估. 自然资源学报, 2003, 18(2): 189-196. [XIE G D, LU C X, LENG Y F, et al. Ecological assets valuation of the Tibetan Plateau. Journal of Natural Resources, 2003, 18(2): 189-196.]

[20] 谢高地, 张彩霞, 张雷明, 等. 基于单位面积价值当量因子的生态系统服务价值化方法改进. 自然资源学报, 2015, 30 (8): 1243-1254. [XIE G D, ZHANG C X, ZHANG L M, et al. Improvement of the evaluation method for ecosystem service value based on per unit area. Journal of Natural Resources, 2015, 30(8): 1243-1254.]

[21] 王少剑, 方创琳, 王洋. 京津冀地区城市化与生态环境交互耦合关系定量测度. 生态学报, 2015, 35(7): $2244-2254$. [WANG S J, FANG C L, WANG Y. Quantitative investigation of the interactive coupling relationship between urbanization and eco-environment. Acta Ecologica Sinica, 2015, 35(7): 2244-2254.]

[22] 邓越, 蒋卫国, 王文杰, 等. 城市扩张导致京津冀区域生境质量下降. 2018, 38(12): 4516-4525. [DENG Y, JIANG W G, WANG W J, et al. Urban expansion led to the degradation of habitat quality in the Beijing-Tianjin-Hebei Area. Acta Ecologica Sinica, 2018, 38(12): 4516-4525.]

[23] 刘纪远, 宁佳, 匡文慧, 等. 2010-2015 年中国土地利用变化的时空格局与新特征. 地理学报, 2018, 73(5): 789-802. [LIU J Y, NING J, KUANG W H, et al. Spatio-temporal patterns and characteristics of land-use change in China during 2010-2015. Acta Geographica Sinica, 2018, 73(5): 789-802.]

[24] 丁丽莲, 王奇, 陈欣, 等. 1984-2014年淀山湖地区生态系统服务价值对土地利用变化的响应. 生态学报, 2019, 39 (8): 2973-2985. [DING L L, WANG Q, CHEN X, et al. The responses of ecosystem services to land-use change in Dianshan Lake area from 1984 to 2014. Acta Ecologica Sinica, 2019, 39(8): 2973-2985.] 


\title{
Study on the wetland leading service function of Jing-Jin-Ji Urban Agglomeration based on the ecosystem service value
}

\author{
LI Zhuo ${ }^{1,2}$, JIANG Wei-guo ${ }^{1,2}$, WANG Wen-jie ${ }^{3}$, LYU Jin-xia ${ }^{1,2}$, DENG Yue ${ }^{1,2}$ \\ (1. Beijing Key Laboratory for Remote Sensing of Environment and Digital Cities, Faculty of Geographical \\ Science, Beijing Normal University, Beijing 100875, China; 2. State Key Laboratory of Remote Sensing \\ Science, Faculty of Geographical Science, Beijing Normal University, Beijing 100875, China; \\ 3. Chinese Research Academy of Environmental Sciences, Beijing 100012, China)
}

\begin{abstract}
Wetland is one of the three major ecosystems of the Earth, which plays an important role in climate regulation, water supply and environmental purification. Based on the land ecological remote sensing interpretation data and socio-economic data from 1990 to 2015, this research quantitatively studied the change of ecosystem service value of different wetland types and different functions in the Beijing-Tianjin- Hebei (Jing-Jin-Ji) Urban Agglomeration and each city by modifying the ecosystem service equivalent value, and the wetland function was orientated by calculating the internal and external contribution rates of the wetland value. The results showed that: (1) The ecosystem service value of wetland in Jing- Jin- Ji Urban Agglomeration showed a trend of rising first and then wavily descending. The wetland value in 2015 increased by $2.93 \times 10^{9}$ yuan compared with 1990 , mainly due to the increase of the value of river canals, reservoirs and ponds, as well as the increase of hydrological regulation value and water supply value. (2) Among the 13 cities in the Jing- Jin- Ji Urban Agglomeration, Tianjin had the highest ecosystem services value, and wetland value in the eastern coastal regions had increased. Inland cities in the south not only had a small wetland area, but their value had also declined year by year. (3) Hydrological regulation, water supply and environmental purification were the dominant functions of most urban wetlands in the urban agglomeration, while river canals, reservoirs and flood land were the main types of wetlands that provided service functions. The reduction and increase of ecosystem services value were closely related to human activities. Therefore, understanding the changing trend of wetland value and clarifying the functional orientation of wetland can not only enhance people's awareness of wetland ecological protection, but also provide scientific basis for the protection, restoration and sustainable use of wetland in the Jing-Jin-Ji Urban Agglomeration in the future.
\end{abstract}

Keywords: Jing-Jin-Ji Urban Agglomeration; wetland; ecosystem service value; function orientation 